\title{
A Study on Science Students' Understanding of Three Lemmas: State Verb, Action Verb and Noun in the State Run Colleges in Pakistan
}

\author{
Muhamma Imran ${ }^{1}$, Tahira Asgher ${ }^{2} \&$ Mamuna Ghani ${ }^{3}$ \\ ${ }^{1}$ Govt. Post Graduate College, Burewala, Pakistan \\ ${ }^{2}$ Govt. Sadiq College Women University, Bahawalpur, Pakistan \\ ${ }^{3}$ Department of English, The Islamia University of Bahawalpur, Pakistan \\ Correspondence: Tahira Asgher, Govt Sadiq College Women University, Bahawalpur, Pakistan. E-mail: \\ abeehamalika@gmail.com
}

Received: July 25, 2016 Accepted: August 16, 2016 Online Published: September 23, 2016

doi:10.5539/ijel.v6n5p121 URL: http://dx.doi.org/10.5539/ijel.v6n5p121

\begin{abstract}
English main verbs are classified as stative and dynamic. At first, this paper deals with the analysis of stative verbs, highlights their true nature and function and illustrates the concept of spontaneity within the state verbs. Secondly, it expounds how the term 'lemma' helps in sorting out the same words representing different parts of speech. Finally, it reports on the level of the science students' competency in the use of state verbs, action verbs and nouns. For this purpose, 300 science students of intermediate level were selected as participants for the present study. A language proficiency test was conducted to collect data. The results revealed that majority of the students had scanty understanding of nouns and state verbs but their recognition of action verbs had been of average level. Some suggestions for improved pedagogy in teaching English grammar have been suggested on the basis of these findings.
\end{abstract}

Keywords: stative verbs, action verbs, nature, function, lemma, competency

\section{Introduction}

Noun and verb are two semantic based grammatical categories that make a piece of discourse. Noun and verb have come closer to each other as subject-verb (SV) sentence structure is very common where subject is, most of the times, a noun. SVO order is the most common order used by number of speakers, and the second most common order by number of known languages and is used in more than $75 \%$ of the world's languages. Nouns are much more common in academic writing than in registers. Biber et al. (1999) reports almost 300 thousand nouns per million words are used in academic writing. The problem with the students at intermediate level in our colleges is that they don't know the role of noun and verb in the whole drama of sentence construction and for the most often, find it difficult to identify them. They don't have thorough understanding of true nature and function of noun, state verb and action verb and as such happen to construct grammatically incorrect sentences which arguably accounts for their lack of proficiency in the language use.

\subsection{Noun}

A noun, derived from Latin word nomen (name), is a part of speech that denotes a person, thing or place. Approximately, every language has words that are nouns. Nouns are of different type i.e., concrete, abstract, common, proper, countable, non-countable, material and collective noun etc.

\subsubsection{Concrete Noun}

A concrete noun is the name of a thing, person or place that can be seen, heard, smelt, tasted or touched. For example: apple, Joe, school, tree and flowers etc.

\subsubsection{Abstract Noun}

An abstract noun is the name of an idea, person or place that cannot be seen, heard, smelt, tasted or touched. They can be felt only. However, sometimes it can be difficult to recognize an abstract noun when we come across with the words that fall in more than one part of speech. Love and taste are the examples of such a case. In she loves her mother, the word love is a stative verb whereas in God is love the word love is an abstract noun. Similarly, the semantic and syntactic difference in taste can be noted in the sentences the taste of the cakes was 
very good and the mangoes taste sweet.

\subsubsection{Material Noun}

A material noun is the name of a material or a substance or an ingredient of an alloy. In other words we may say that it is the name of material with which other things are made. It refers to the type of the material rather than its particles. For example: rice, wheat, water, *exene, steel and gold etc. Material nouns are not countable. Neither have they taken plural forms nor support articles.

\subsubsection{Collective Noun}

A collective noun refers to a collection of things taken as a whole. For example: team, herd, choir, chorus, family and army etc. A collective noun usually demands the singularity or plurality of the verb and pronoun depending on the semantic structure of the sentence. A collective noun demands singular verb and pronoun when the individuals are part of collective noun as in the herd of sheep follows its shepherd to the pool. Similarly, a collective noun demands plural verb and pronoun when members of a collective noun act as individuals as in the jury look at their watches and head to their cars.

\subsection{Action Verb}

"Dynamic" is an adjective which means something is moving or changing. In English grammar, dynamic verbs describe an action rather than a state. Dynamic verbs are also known as action verbs or fientive verbs. The sentence that contains an action verb usually has a subject which functions as an agent that transits its action (behavior) through the verb onto the object and thus, action verbs are often considered transitive in nature. An action verb tells what action (often a physical action) a subject is performing, has performed, or will perform. For example:

a. My father delivers packages to departmental stores each day.

b. Joe skated across the rink in Central Park.

c. Oscar will help Joe with the project.

\subsection{Stative Verbs}

Smith (1991) reports that English main verbs are classified as states and events. The events are dynamic which involve change, activity and role of agent whereas the states are static which denote the occurrence of an event with no end point. The matter of fact is that stative verbs represent indefinite events (with no end point) befalling spontaneously and thus, they correspond to the present indefinite tense rather than progressive aspect. Statements about rules of nature and the way the world is are described in the present simple tense. It means that a verb may be stative if the process of its occurrence (be) demonstrates spontaneity. Leech, Hundt, Mair, \& Smith (Change in Contemporary English: A Grammatical Study. Cambridge University Press, 2012) assert that our analysis is based upon previously presented proposals especially by Leech 2004 and Huddleston \& Pullum 2002, that divide verbs giving stative interpretations into four semantic classes:

a. Perception and sensation (e.g., see, hear, smell, hurt, taste)...

b. Cognition, emotion, attitude (e.g., think, feel, forget, remember)...

c. Having and being (e.g., be, have, cost, require)..

d. Stance (e.g., stand, lie, live, face)

\subsubsection{State Verbs and Transitivity}

A transitive verb always has the property of transitivity (to pass through) in which the action begins with the subject and passes through the verb to the object. The intransitive verbs may be state verbs but it is not true all the time as in "Joe jumped down from the terrace". Similarly, it is not necessary all the time that the state verbs are not transitive as in "Maggie knows where Stephen lives".

\subsubsection{State Verbs and Progressive Aspect}

A general distinction is made on the ground that dynamic verbs correspond to progressive aspect as in "they are growing crops" whereas the state verbs do not as in (*the crops are growing rapidly). The distinction made on the basis of progressive aspect may be confusing. "[a] stative situation is one in which there is no movement or change.

Therefore, putting a stative verb into the progressive construction sets up a logical contradiction —an action cannot be both dynamic and stative at the same time!" (Payne, 2011) 


\subsubsection{Subject, Agent and State Verbs}

Various studies see a distinction between the subject and the agent in linguistics. All agents may be the subject being antecedent of the sentence but all subjects are not necessarily agents. The subject of a sentence is a syntax based concept whereas an agent is semantic based. The subject is determined through word order or flow of information while the agent transits its action through the verb onto the patient. In Joe kicked the football, Joe is an agent passing its action through verb kicked onto the patient the football. Lee (1971) and Ross (1972) argues that dynamic verbs have agents, which transit energy and volition whereas the stative verbs do not have.

\subsubsection{Subject, Agent and Spontaneity in State Verbs}

The state verbs represent the events that occur spontaneously and no agent transits its action onto the patient but the flow of information or the word order determines the subject of the sentence. For instance,

- The water flows in the canal.

"Flow" represents a spontaneous event. In the above sentence, it is not being performed by any agent. The subject "water" doesn't transit its action through the verb "flow" rather, whatever flows (water) is an object presently working as subject.

- $\quad$ The water evaporates.

"Evaporation" is a spontaneous event. It is not being performed by any agent. The subject "water" doesn't pass its action through the verb "evaporate". "The sun evaporates the water" has an agent that passes its action through the verb onto its object.

- The water level falls by slow degrees.

"Fall" represents an event that occurs spontaneously. It is not being performed by any agent. The subject "water" doesn't pass its action through the verb "fall".

- $\quad$ Blood pumps out of his wound.

Here, "Pump" represents a spontaneous event. It is not being performed by any agent. The subject "Blood" doesn't transit its action through the verb "pump". "The heart pumps the blood around the body" has an agent that passes its action through the verb onto its object.

- $\quad$ Shakespeare writes.

Writing a piece of literature is a process that occurs only in a peaceful state of mind when gathered ideas from primary imagination along with poetic impulse make an amalgam in secondary imagination to generate poetry. So writing poetry etc. is not an endeavor rendered on the part of the writer himself rather it is a spontaneous overflow of powerful feelings. "Wordsworth writes poetry" has a subject that does not pass its action through the verb onto its object.

- Shakespeare takes a fancy to objects of Nature.

"Fancy" is a box in human mind that stores within it what is perceived by the five senses and is responsible for what we like or dislike. This is not an act done on the part of writer. This is a spontaneous event that occurs in a moment of tranquility.

\section{- I squeeze.}

"Squeezing" is a spontaneous event that a man cannot retard intentionally even when he wants to. This is because it is a natural process that occurs spontaneously.

\section{- $\quad$ The eyes blink.}

Blinking of eyes is natural and universal to all. Except for a few, all animals including human beings blink eyes. Even they are not conscious of this activity of theirs. It is because this is a spontaneous event that cannot be dispensed with.

\section{- $\quad$ The wood floats.}

"Float" is a state verb because nothing (agent) causes the wood float in this sentence. It is a general quality of the wood that it floats on the surface of water. The wood does not pass its action through float. Rather whatever floats is wood.

- $\quad$ The child grows.

"Grow" is a state verb because the process of growth continues spontaneously even if there is none to support one to grow, like a fictional character "Tarzan". The child is subject not agent. 


\subsection{Lemma}

When a particular word falls in the category of different parts of speech at the same time, it is lemma that provides them asylum. Francis \& Kulera (1982) observes that a lemma usually comprises on a head word and inflected forms attached to it and some of its reduced forms (don't). Generally, the items that are considered as a lemma must be of same part of speech. But worth mentioning point here is that same form (look) used as different parts of speech (look as a verb, look as a noun) does not come in the category of the same lemma but different lemmas. Some words are used with variant spellings (organize, organise; color, colour) are considered as a part of same lemma with one condition that they are the same part of speech.

The following lemma concordance contains the words which simultaneously fall in three different parts of speech i.e., action verb, state verb and noun.

\begin{tabular}{|c|c|c|c|}
\hline Word & Action Verb & State Verb & Noun \\
\hline Age & $\begin{array}{l}\text { They have aged the wine in the deep } \\
\text { delved earth. }\end{array}$ & As he aged, his memory got worse. & He left school at the age of 18. \\
\hline Bath & He bathed his kids in the pond. & The plants bath in rain in April. & $\begin{array}{l}\text { Please run a bath for me (fill the } \\
\text { bath with water). }\end{array}$ \\
\hline Bear & I cannot bear all these expenses. & This joke doesn't bear repeating. & We saw a bear in the jungle. \\
\hline Beat & Someone was beating a drum. & Hailstones beat against the window. & Our hearts miss a beat in fear. \\
\hline Blow & $\begin{array}{l}\text { He draws on his cigarette and blows out a } \\
\text { stream of smoke. }\end{array}$ & Cool breeze blows from the East. & $\begin{array}{l}\text { Give your nose a good blow (= clear } \\
\text { it completely). }\end{array}$ \\
\hline Break & He breaks the sticks. & She breaks silence by coughing. & She works without break. \\
\hline Burn & The automobiles burn petrol. & A welcoming fire burns in a party. & I found cigarette burns. \\
\hline Cheer & $\begin{array}{l}\text { The people cheer the president as he } \\
\text { drives by them. }\end{array}$ & $\begin{array}{l}\text { We all cheer as the team comes on to } \\
\text { the field. }\end{array}$ & $\begin{array}{l}\text { A great cheer went up from the } \\
\text { crowd. }\end{array}$ \\
\hline Clean & I want to clean the window. & This oven cleans easily. & The house needed a good clean. \\
\hline Close & I closed my eyes to sleep. & This offer closes on Monday. & Dollar gained at the close of day. \\
\hline Cost & I have costed the project at $\$ 8.1 \mathrm{~m}$. & These tickets cost ten dollars each. & I can afford the cost of pills. \\
\hline Cut & He cut thick slices from the loaf. & Sandstone cuts easily. & Blood poured from the deep cut. \\
\hline Drop & He dropped his pants. & The valley drops away from road. & There was a sheer drop of rocks. \\
\hline End & They end their relations with him. & The road ends here. & The end of novel was interesting. \\
\hline Face & He faced the dragon with a sword. & Their houses face the river. & I saw his face in the mirror. \\
\hline Fall & The old man was falling a tree. & The water level falls by June. & She died in a fall from a horse. \\
\hline Fail & $\begin{array}{l}\text { The examiners failed over half the } \\
\text { students. }\end{array}$ & $\begin{array}{l}\text { Her eyesight is failing with slow } \\
\text { degrees. }\end{array}$ & $\begin{array}{l}\text { The teacher got three passes and one } \\
\text { fail. }\end{array}$ \\
\hline Feel & Do you know how to feel pulse? & I feel that you are wrong. & $\begin{array}{l}\text { The fluffy hairs make a pleasant } \\
\text { feel. }\end{array}$ \\
\hline Fill & The wind filled the sails. & The sails fill with wind. & The guests had eaten to their fill. \\
\hline Fit & We fitted together the parts. & I tried the dress on but it didn't fit. & Often, melancholy fit falls. \\
\hline Flap & The bird flapped its wings to fly. & The sails flap in the breeze. & Flap of bird's wings was heard. \\
\hline Freeze & The weather froze the ground. & Water freezes at $0^{\circ} \mathrm{C}$. & A freeze warning was alarmed. \\
\hline Gain & At last she gained the shelter of the forest. & $\begin{array}{l}\text { The euro gained against the dollar again } \\
\text { today. }\end{array}$ & $\begin{array}{l}\text { He only seems to be interested in } \\
\text { personal gain. }\end{array}$ \\
\hline Go & She goes to school daily. & Her hair is going grey. & Wait for my go. \\
\hline Jump & She jumps from her window. & Prices jumped by $60 \%$ last year. & The horse fell at the last jump. \\
\hline Look & I look out of the window. & You look gorgeous. & You need to change your look. \\
\hline Mind & Mind your head! (save) & She never minds how hot it is. & The mind generates thoughts. \\
\hline Miss & You missed a good party last night. & I miss that time. & Good morning, Miss! \\
\hline Notice & $\begin{array}{l}\text { I did not notice them to come in. (to } \\
\text { signal) }\end{array}$ & $\begin{array}{l}\text { The first thing I noticed about the room } \\
\text { was the smell. }\end{array}$ & $\begin{array}{l}\text { A public notice about the planned } \\
\text { development was pinned. }\end{array}$ \\
\hline Part & He parts his hair in the middle. & The crowd parted in front of them. & I bought some parts of machine. \\
\hline Pass & They passed me jam. & Sweet time passes smoothly. & I got pass for stadium. \\
\hline Pay & I'll pay for the tickets. & You'll pay for that remark! & Her pay is sound. \\
\hline Peep & She peeps through her fingers. & The tower peeped above the trees. & Joe took a peep at the last page. \\
\hline Pile & $\begin{array}{l}\text { She piled the boxes one on top of the } \\
\text { other. }\end{array}$ & $\begin{array}{l}\text { Problems piled up at the arrival of } \\
\text { Spring. }\end{array}$ & I have got piles of work to do. \\
\hline Play & She plays football. & DVD cannot play on my computer. & We need more play in the rope. \\
\hline Pound & $\begin{array}{l}\text { They pound (to break it into smaller } \\
\text { pieces) the seeds. }\end{array}$ & $\begin{array}{l}\text { Rock music was pounding out from the } \\
\text { jukebox. }\end{array}$ & $\begin{array}{l}\text { The pound closed slightly down at } \\
\$ 1.534 \text {. }\end{array}$ \\
\hline Pump & $\begin{array}{l}\text { The heart pumps the blood around the } \\
\text { body. }\end{array}$ & Blood was pumping out of his wound. & $\begin{array}{l}\text { She washed her face at the pump in } \\
\text { front of the inn. }\end{array}$ \\
\hline Rain & The volcano rained hot ashes. & It hardly rains in summer. & Do not go outside in heavy rain. \\
\hline Ring & I rang her yesterday. & The home rang with children' laughter. & I have bought a precious ring. \\
\hline Read & Do they read newspaper daily? & The sign board reads: Stop. & A novel is a good read. \\
\hline Roll & She rolled her eyes upward. & The stone rolled down the hill. & We ate a chicken roll. \\
\hline
\end{tabular}




\begin{tabular}{|c|c|c|c|}
\hline Run & He runs his business efficiently. & The water runs through the fingers. & Austria made two hundred runs. \\
\hline Set & I set my watch by the TV. & The sun sets in the west. & I have a new set of dishes. \\
\hline Shift & He shifted his gaze from the child to her. & $\begin{array}{l}\text { The action of the novel shifts from } \\
\text { Paris to London. }\end{array}$ & $\begin{array}{l}\text { The night shift has just come off } \\
\text { duty. }\end{array}$ \\
\hline Show & He showed me a picture of his childhood. & Fear shows in his eyes. & $\begin{array}{l}\text { She may seem charming, but it's all } \\
\text { show! }\end{array}$ \\
\hline Shower & He showers gifts on her. & $\begin{array}{l}\text { Volcanic ash showers down after } \\
\text { eruption. }\end{array}$ & We enjoyed shower in bath. \\
\hline Smell & They smell the fume of the flowers. & Those flowers smell good. & The smell kills the nostrils. \\
\hline Smoke & She smokes heavily. & This fireplace smokes badly. & I disdain the smoke of cigarette. \\
\hline Spring & $\begin{array}{l}\text { He turned off the alarm and sprang out of } \\
\text { bed. }\end{array}$ & $\begin{array}{l}\text { The branch sprang back and hit him in } \\
\text { the face. }\end{array}$ & Flowers bloom in spring. \\
\hline Sprout & $\begin{array}{l}\text { Joe has sprouted (to start to grow) a beard } \\
\text { since we last saw him. }\end{array}$ & The buds will sprout in a few days. & $\begin{array}{l}\text { Once I tasted russels sprout (a } \\
\text { small round green vegetable like a } \\
\text { very small cabbage). }\end{array}$ \\
\hline Stand & $\begin{array}{l}\text { They stand the little girl on the table so } \\
\text { that she may see. }\end{array}$ & $\begin{array}{l}\text { Does her house stand on the way to } \\
\text { woods? }\end{array}$ & $\begin{array}{l}\text { I made a stand of steel to pick } \\
\text { apple. }\end{array}$ \\
\hline Stream & $\begin{array}{l}\text { You can stream the song for a single } \\
\text { listen. }\end{array}$ & $\begin{array}{l}\text { Tears stream down her face when she } \\
\text { receives set back. }\end{array}$ & $\begin{array}{l}\text { He blew out a stream of cigar } \\
\text { smoke. }\end{array}$ \\
\hline Strike & The killer can strike. ( to attack) & The ship struck a rock. & The workers went on strike. \\
\hline Take & A boy took us to our room. & $\begin{array}{l}\text { It will take about half an hour to get to } \\
\text { the airport. }\end{array}$ & $\begin{array}{l}\text { What's his take on the plan?( the } \\
\text { particular opinion or idea) }\end{array}$ \\
\hline Taste & They taste the vintage. & The grapes taste sour. & The taste of milk is amazing. \\
\hline Tear & I can tear canvas with hands. & These fabrics tear very easily. & This sheet has a tear in it. \\
\hline Think & $\begin{array}{l}\text { I am thinking about } 70 \text { guests in the } \\
\text { wedding. }\end{array}$ & $\begin{array}{l}\text { Man can think well than other } \\
\text { creatures. }\end{array}$ & $\begin{array}{l}\text { I'll have a think and let you know } \\
\text { tomorrow. }\end{array}$ \\
\hline Turn & $\begin{array}{l}\text { They turn their cars to the end point } \\
\text { during race and win. }\end{array}$ & $\begin{array}{l}\text { They turn pale as they find a lion close } \\
\text { to them. }\end{array}$ & The tourists took a wrong turn. \\
\hline Wear & She always wears black. & He wears well — only a few grey hairs! & $\begin{array}{l}\text { We have casual dresses for everyday } \\
\text { wear. }\end{array}$ \\
\hline Wink & $\begin{array}{l}\text { She winks her eyes fast in her dramatic } \\
\text { mood. }\end{array}$ & $\begin{array}{l}\text { Man's eyes wink but this is not the case } \\
\text { with snakes. }\end{array}$ & $\begin{array}{l}\text { The hero killed the dragon within a } \\
\text { wink. }\end{array}$ \\
\hline
\end{tabular}

\section{Literature Review}

Several studies have been conducted to explore the true nature and function of state verbs and as many linguists have probed into the phenomenon, as many sundry definitions have been brought forward. Leech (2004) includes the verbs such as agree, believe, fear, hope, know, like, realize, regret, suppose, think, understand, wish and many more in the category of 'inert' verbs, as well as the verbs of perception, which means that they do not evince any effort or intention. Together the approaches of Debopam (2010) and the authors, like Hirtle (1967), Quirk et al. (1972) or Vendler (1968) divide state verbs into four categories.

1) Verbs of perceiving

Verbs such as feel, hear, see, smell, taste etc. show a physical perception. According to Palmer (1988) these verbs are termed as "private verbs" as only the speaker himself can sense them.

2) Verbs referring to a state of mind or feeling

These verbs denote emotions, attitudes and intellectual states. Verbs such as believe, adore, desire, detest, dislike, doubt, forget, hate, imagine, know, like, love, mean, prefer, remember, suppose, understand, want, wish etc. fall under this category.

3) Verbs referring to a relationship or a state of being

These verbs such as belong to, concern, consist, include, involve, own, possess, represent, and resemble etc. express relationships between entities.

4) Verbs referring to internal sensations

According to Leech et al. (2002) verbs such as ache, feel, itch, hurt etc. fall under this category. These verbs are least non progressive.

According to Fowler, Roger (2010) some sentences contain an associated noun in a certain state as in Joe is tall, Stephen was weak, the house smells and this shirt is dry. The stative form of these predicates can be conformed through certain transformational tests: they do not take the imperative mood (*Be dry!); they are unable to answer What did X do? or What happened to X?; they do not correspond to the progressive aspect $\left({ }^{*}\right.$ Joe is being tall). The failure of the imperative, the progressive and the do-question tests reveal that these predicates do not 
communicate actions.

Even the matter of putting the stative verbs into progressive aspect seems to be controversial. MILLER, in $A$ Critical Introduction to Syntax (2011), corroborated by Quirk et al. (1985) says that the most stative verb of the stative verbs like know does not correspond to progressive aspect but at least at the time of writing, many stative verbs do allow it. Nonetheless, Payne (2011) expounds that no movement or change can occur in a stative situation therefore, putting a stative verb into the progressive aspect generates a logical contradiction —an action cannot be both dynamic and stative at the same time.

The matter of extracting an exact and precise definition of state verb seems to be an enigma perhaps because of the controversy over putting the state verbs into progressive aspect and involvement of abstract (perception, feelings and sensation) in its definition.

However, a word may be used as stative verb and noun in two separate constructions and a term comes to differentiate them i.e., Lemma. Traditionally, a noun is defined as a word that names "a person, place, thing, or idea" (Weaver, 1996). Cullip (2000) is of the view that nouns are tools with many strengths. Noun phrases have elasticity; they "can be stretched syntactically and packed semantically" (p. 85) in ways that other phrases, such as verb phrases, cannot. Levelt (1989) points out that lemmas and forms are two parts of the lexicon. The lemmas usually consist of semantic knowledge i.e., the knowledge of the meaning of a word, and grammatical knowledge - the knowledge of the syntactic category i.e., part of speech of a word, its grammatical functions, restrictions and marking that determine its use, such as person, number, tense etc. (p. 183).

\section{Research Methodology}

\subsection{Instrument}

For data collection, a language proficiency test comprising on fifteen sentences was conducted in which each cluster of three sentences was designed in a way that same word in each individual sentence of the cluster was used as state verb, action verb and noun. These five words (smell, taste, read, run, and feel) were chosen carefully in a way that each word could fall in three lemmas i.e., action verb, state verb and noun simultaneously. These words used in each sentence were highlighted for convenience in identification. Three options (A, S, N) that stand for action verb, state verb and noun respectively, appeared against each sentence. The participants were asked to select one option out of the three.
a) Do you know how to feel the pulse?
A $S \mathrm{~N}$
b) I feel that you are wrong.
c) Her fluffy downs make me a pleasant feel.

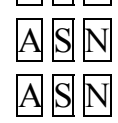

\subsection{Procedure}

The test was conducted in the state run colleges. The science students $(\mathrm{N}=300)$ of intermediate level were 150 male and 150 female who participated in this non experimental research. The formula of percentage of overall correct answers was applied to evaluate the data.

The performance of the students was graded on a 1 to 4 Likert- scale in which below forty corresponded to very poor, below fifty to poor, fifty plus to average and sixty plus to good level of understanding.

\section{Results}

The responses to the language proficiency test were analyzed via descriptive statistics. For the purpose of this study, the analysis focused on the percentage of overall correct answers to find out the science students' understanding of noun, state verb and action verb, and the ratio of male participants to female participants to find out whether the male participants or female participants have better understanding level. The language proficiency test revealed the findings displayed in Table $1 \& 2$.

Table 1. Percentage of overall correct answers

\begin{tabular}{lllll}
\hline Category & Overall Correct Ans. & Overall Incorrect Ans. & Overall Correct \& Incorrect Ans. & $\begin{array}{l}\text { Percentage of Overall Correct } \\
\text { Ans. }\end{array}$ \\
\hline Noun & 626 & 874 & 1500 & $42 \%$ \\
State Verb & 688 & 812 & 1500 & $46 \%$ \\
Action Verb & 862 & 638 & 1500 & $57 \%$ \\
\hline
\end{tabular}


It can be seen from Table 1 that the participants' understanding of action verb was satisfactory whereas that of noun and state verb remained below fifty percent. Table 2 expounds that the male participants outbid female participants in their understanding of noun whereas the female participants outdistanced the male participants in their understanding of state verb and action verb.

Table 2. Ratio of male to female about understanding

\begin{tabular}{lllll}
\hline Lemma & Number of Participants & $\begin{array}{l}\text { Percentage of Correct Ans. } \\
\text { of Male participants }\end{array}$ & $\begin{array}{l}\text { Percentage of Correct Ans. } \\
\text { of Female participants }\end{array}$ & $\begin{array}{l}\text { Ratio of Male participants to } \\
\text { Female participants }\end{array}$ \\
\hline Noun & 150 & $46 \%$ & $38 \%$ & 1.21 \\
State Verb & 150 & $44 \%$ & $47 \%$ & 0.94 \\
Action Verb & 150 & $56 \%$ & $59 \%$ & 0.95 \\
\hline
\end{tabular}

\section{Discussion}

It is evident from the results that the students were facing difficulty in identifying different parts of speech. They seemed to be entangled in the perplexing grammatical aspects that they needed to understand. The percentage of overall correct answers of 300 male and female participants related to noun, state verb and action verb were $42 \%$, $46 \%$ and $57 \%$ respectively. This analysis revealed that the participants had poor understanding of noun and state verb but their understanding of action verb was of average level. Gillette, Gleitman, Gleitman, \& Lederer, (1999) and Snedeker \& Gleitman, (2004) also conducted similar experiment with same results, in which adults viewed a series of silent video clips of a mother and child playing where participants were asked to guess the nouns and verbs. The results demonstrate that the proportion of correctly guessed the missing nouns is $45 \%$ and those of verbs is a paltry $15 \%$. In fact, if only responses for stative verbs are considered, the proportion of correct verb guesses drops to $0 \%$.

A similar study was conducted by Halliday in which the sample was the science students. As far as the science students' understanding of the noun in the present study was concerned, it was discovered that they had poor level of understanding and these findings seem to reconcile with Halliday's statement "a pile-up of nouns ... is hard to understand both for [English L1 and L2] ... students of science" (1993, p. 69).

It is generally believed that practice facilitates the accuracy, and accuracy targets on the correct use of grammar of the language. The English teachers should not only present the rules of the grammar but should also make them understandable by involving the students in activity based exercises in the class room. Jones \& Lock (2011, p. 73) argue with the learners that "Elaborating activities can help unmask the fact that learning grammar is not just about "correctness" but that it is first and foremost about gaining control over resources for making communication more effective". But it is absolutely true that the learning of grammar is a complex, multifaceted, and lengthy process and no single pedagogical approach can claim priority in teaching (Ellis \& Shintani, 2014).

Table 2 demonstrates that the male participants had poor understanding of noun because the percentage of the overall correct answers of the male participants about noun was $46 \%$ and the analysis revealed that the female participants had very poor level of understanding of noun as the percentage of the overall correct answers was a paltry $38 \%$. Together the male and female participants' understanding of state verbs was of poor level because the percentages of their overall correct answers were $44 \%$ and $47 \%$ respectively. As for as the action verb was concerned, both the male and female participants' understanding was of average level because their scores reached $56 \%$ and $59 \%$ respectively.

Table 2 also expresses the ratio of male participants to female participants about the understanding of three lemmas i.e., noun, state verb and action verb. According to the results, the male participants' understanding of noun was 1.21 times greater than the female participants' whereas the male participants' understanding of state verbs was .06 times less than the female participants'. Similarly, the male participants' understanding of action verbs was counted .05 times less than the female participants'.

The analysis unmasked that the female science students' understanding about state verb and action verb was greater than the male students'. Though the male students' understanding of noun was better than female students' yet, both the male and female participants' understanding of noun stood at a shocking stage. To reach better results, the course designers and syllabus setters should make the parts of speech an integral part of the syllabus studies and examination system, and classroom tests may also help enhance the understanding of noun and verb i.e., action verbs and state verbs.

During the study, it was discovered that the stative verbs could easily be identified by evaluating the presence or 
absence of spontaneity in the occurrence of the event. The events that occur spontaneously and no external agent works on the phenomenon of that event happening, may readily be called stative verbs or otherwise, action verbs.

\section{Conclusion}

Various revelations of the present study lead to the conclusion that the science students' understanding of noun and state verb is unsatisfactory. The students at intermediate level in the state run colleges find it difficult to identify major parts of speech i.e., noun and verb. The performance of the students may be improved by teaching grammatical features focusing on subject-verb relationship. Though learning of grammar is a complex phenomenon and is often considered boring especially in case of EFL yet, learning of grammar may be made enjoyable and interesting by teaching it through activities. A teacher of grammar should act like a pedant. The study of stative verbs should be given due importance and that the stative verbs can be isolated from dynamic verbs on the basis of presence of spontaneity in the occurrence of the event.

\section{References}

Biber, D., Johansson, S., Leech, G., Conrad, S., \& Finegan, E. (1999). Longman Grammar of Spoken and Written English. London: Longman.

Constance, W. (1996). Teaching Grammar in Context. Portsmouth, NH: Boynton/Cook Heinemann.

Cullip, P. (2000). Text Technology: The Power-Tool of Grammatical Metaphor. RELC Journal, 85. http://dx.doi.org/10.1177/003368820003100204

Debopam, D. (2010). The Uses and Distribution of Non-Progressive Verbs in Progressive Forms: A Corpus-based Study. 26th Northwest Linguistics Conference, Vancouver.

Ellis, R., \& Shintani, N. (2014). Exploring Language Pedagogy through Second Language Acquisition Research. London: Routledge

Francis, W. N., \& Kucera, H. (1982). Frequency Analysis of English Usage. Boston: Houghton Mifflin Company.

Gillette, J., Gleitman, H., Gleitman, L., \& Lederer, A. (1999). Human Simulations of Vocabulary Learning Cognition, 73, 135-176.

Hirtle, W. (1967). The simple and the progressive forms. Quebeck: Les press de Universite Laval

Huddleston, R., \& Geoffrey, P. K. (2002). The Cambridge Grammar of the English Language. Cambridge: Cambridge University Press.

Jones, R. H., \& Lock, G. (2011). Functional Grammar in the ESL Classroom: Noticing, Exploring and Practicing. New York: Palgrave Macmillan. http://dx.doi.org/10.1057/9780230297524

Leech, G. (1971). Meaning and the English Verb. Harlow: Pearson Education Limited.

Leech, G. (2004). Meaning and the English Verb (3rd ed.). Harlow: Longman.

Leech, G., \& Svartvik, J. (2002). A Communicative Grammar of English. London: Longman.

Leech, G., Hundt, M., Mair, C., \& Smith, N. (2012). Change in Contemporary English: A Grammatical Study. Cambridge: Cambridge University Press.

Levelt, W. J. M. (1989). Speaking: From Intention to Articulation. Massachusetts: MIT Press.

Miller, J. (2011). A Critical Introduction to Syntax London. New York: Continuum.

Palmer, F. R. (1988). The English Verb (2nd ed.). London and New York: Longman.

Payne, T. E. (2011). Understanding English Grammar: A linguistic introduction. Cambridge: Cambridge University Press.

Quirk, R., Greenbaum, S., Leech, G., \& Svartvik, J. (1972). A Grammar of Contemporary English. London: Longman.

Quirk, R., Greenbaum, S., Leech, G., \& Svartvik, J. (1985). A Comprehensive Grammar of the English Language. London: Longman.

Ross, J. R. (1972). More on begin. Foundations of Language, 8, 574-577.

Smith, C. (1991). The Parameter of Aspect. Dordrecht: Kluwer. http://dx.doi.org/10.1007/978-94-015-7911-7

Snedeker, J., \& Gleitman, L. (2004). Why is it hard to label our concepts. In G. H. Waxman (Ed.), Weaving a 
lexicon. Cambridge, MA: MIT Press.

\section{Copyrights}

Copyright for this article is retained by the author(s), with first publication rights granted to the journal.

This is an open-access article distributed under the terms and conditions of the Creative Commons Attribution license (http://creativecommons.org/licenses/by/4.0/). 